\title{
SOIL IMPROVEMENT ASSESSMENT. CASE STUDY FIVE STOREY HIGH BUILDING FOUNDATION
}

\author{
Ana Maria Ionita ${ }^{1}$ \\ Sbîrciog Ionela ${ }^{2}$ \\ Ioan Tuns ${ }^{3}$
}

UDK: 624.131 .382

DOI:10.14415/konferencijaGFS 2016.050

Summary: In normal soil conditions, building foundation works represent approximately 15to 18 percent from the total costs and from 12 to 15 percent from the total labour costs. In difficult foundation soils (reduced mechanical resistances) the infrastructure works may exceed 50 percent from the total costs of the investment, thus the chosen foundation system is important from the cost point of view. In the present paper are presented two technical solutions for soil improvement: through piles and through soil injection.

Keywords: soil investigation, soil improvement, soil assessment

\section{INTRODUCTION}

The need to reuse built lands in urban areas often leads to difficult situations regarding geotechnical conditions. Most of the time there are, especially on the site of old industrial plants, infested land networks, buried construction.

The present paper presents the situation of a site where was erected a block of apartments having a height regime of five storeys with a rectangular shape and having the following dimensions of $20,8 \mathrm{~m} \mathrm{x} 30,4 \mathrm{~m}$. The structure is having a plate type foundation system with reinforced concrete frames and walls. The exterior and interior walls are made of brick masonry and Ytong type masonry

The normal combined forces at foundation level is having the values of $3 \cdot 10^{4} \mathrm{~N} / \mathrm{mm}^{2}$ for diaphragms and $6 \cdot 10^{4} \mathrm{~N} / \mathrm{mm}^{2}$ for the concrete columns.

Geotechnical studies carried out on the site have revealed the following layers:

- 0,30 from the natural terrain level - vegetation soil;

- $0,30 \mathrm{~m}$ to $5,00 \mathrm{~m}$ - un-compacted filling;

- 5,00 m to $6,00 \mathrm{~m}$ - sand clay, $I_{c}=0,5-0,75, e=0,80$;

- Over 6 m -sandy clay consistency soil.

\footnotetext{
${ }^{1}$ Faculty of Civil Engineering - Transylvania University of Brasov - student, e-mail: ana.ionita94@ yahoo.com

${ }^{2}$ Faculty of Civil Engineering - Transylvania University of Brasov - student

${ }^{3}$ Faculty of Civil Engineering - Transylvania University of Brasov - Dean, Prof . dr. Eng.
} 


\section{$4^{\text {th }}$ international Conference}

Contemporary achievements in civil engineering 22. April 2016. Subotica, SERBIA

Underground water was encountered at a depth of $5 \mathrm{~m}$ at the level of the natural terrain. The boreholes were performed by Borros 8659 facility, with continuous coring, $112 \mathrm{~mm}$ diameter. From the cohesive material were collected into Shelby tubes.

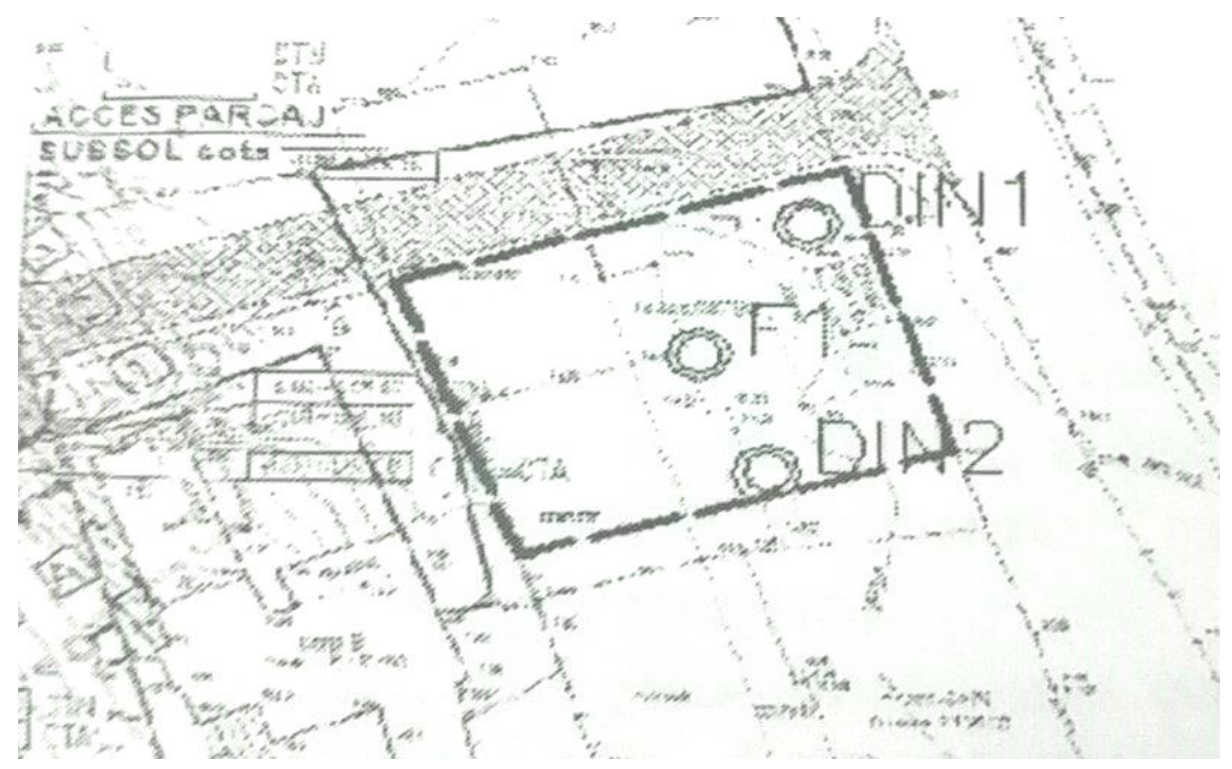

Figure 1. Geotechnical surveys Location Plan

The aspect of the material cropped from the drilling is presented in figure 2 .

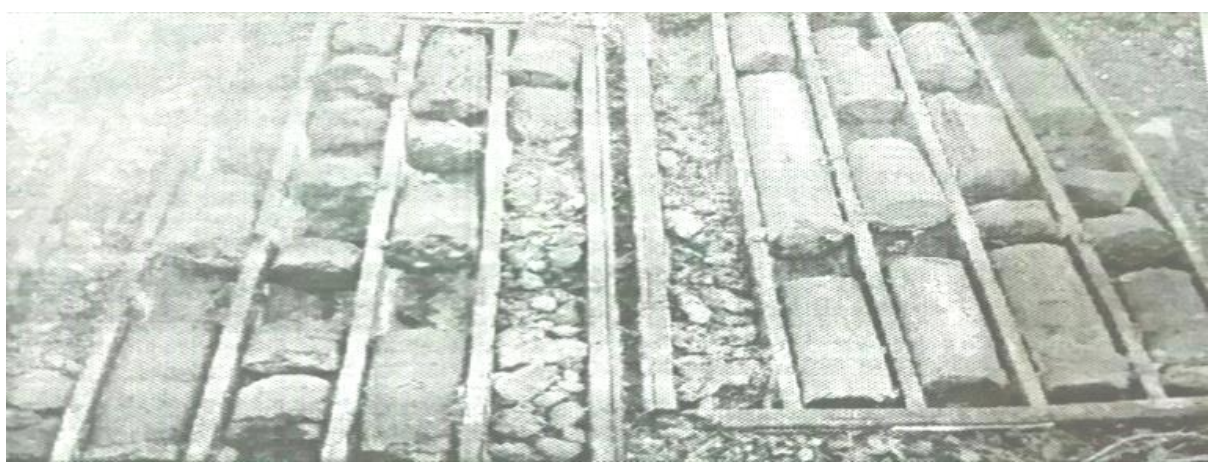

Figure 2. The stratification identified in geotechnical borehole

The processing and interpretation of the data obtained from the geotechnical studies carried out on site, have highlighted the reduced load capacity of the soil at the level of foundation and have revealed the need to improve the soil structure. 
Following procedures were taken into acount: a) Improvement with gravel piles; b) Improvement with soil piles; c) Improvement with gravel cushion; d) Improvement by material injection (e.g.: cement).

The choice of the optimal and economical solutions for improvement of the soil structure was made on the comparative processes investigation.

On the basis of this criteria, for the analysis was taken into consideration that the processes for the soil consolidation using gravel piles or by injections are practically possible in field conditions and thus a lower costs are achieved compared with the other processes. Both procedures were agreed by the investor.

\section{DESCRIPTION OF THE SOIL IMPROVEMENT SOLUTIONS}

The comparison between the two solutions was made technical-economic and technological point of view.

Gravel piles solution

For the bore hole machinery type was taken into account the diameter and the length of the pile from the minimum fixing condition $-2 \times \mathrm{d}$ (where $\mathrm{d}$ is the diameter of the pile) in the consistent clay layer and the load capacity of a pile.

Thus was chosen the Franki type bore hole solution with cast in cast recoverable steel tubes with a $560 \mathrm{~mm}$ diameter for the piles and for a depth of $5,60 \mathrm{~m}$ measured from the lower part of the excavation.

The chosen soil improvement was checked from the capacity point of view at the level of the slab foundation.

$$
E_{d} \leq R_{d}
$$

where $E_{d}$ the value of the effect of the actions and $R_{d}$ the value of the resistance to an action.

In terms of actual and reactive pressure, the relationship become:

$$
\begin{gathered}
p_{\text {ef,max }} \leq p_{\text {conv }} \\
p_{\text {ef,max }}=\omega \cdot \frac{V_{d, F}}{A}
\end{gathered}
$$

where $p_{e f, \max }$ is the effective maximum pressure at the level of the slab foundation; $\omega$ coefficient depending on the eccentricity for the application of the loads transmitted by the construction; $V_{d, F}$ is the vertical force in fundamental group; $p_{c o n v}$ is the conventional pressure of the soil.

$$
p_{e f, \max }=\frac{V_{d, F}}{\alpha \cdot B} \pm \frac{6 \cdot M_{B}}{\alpha^{2} \cdot B} \pm \frac{6 \cdot M_{L}}{\alpha \cdot B^{2}}
$$

where $\alpha$ and $\beta$ are the dimensions in plan of the slab foundation; $V_{d, F}, M_{B}, M_{L}$ are the values of resistances on the level of foundation

$$
p_{\text {conv }}=\overline{p_{c o n v}}+C_{B}+C_{D}
$$


Contemporary achievements in civil engineering 22. April 2016. Subotica, SERBIA

where $\overline{p_{c o n v}}$ conventional pressure; $C_{B}$ and $C_{D}$ are the pressure-correction after the width and height.

Thus resulted the necessity of improving the foundation soil or changing the foundation soil.

$$
p_{\text {ef, } \max }=3,12 \times 10^{4} \mathrm{~N} / \mathrm{mm}^{2}>\text { pconv }=1,80 \times 10^{4} \mathrm{~N} / \mathrm{mm}^{2}
$$

Having established the initial data relating to dimensions of geometric columns in the gravel material and soil, were determined theoretical distance between the piles with the relation:

$$
l=d_{c}=\sqrt{\frac{100-n_{f}}{n_{i}-n_{f}}}
$$

where $d_{c}$ is the diameter of the gravel pile; $n_{i}$ is the initial porosity of the soil; $n_{f}$ is the final porosity of the soil.

Thus resulted the distance between the piles of $l=1,20 \mathrm{~m}$.

The bearing capacity of a gravel pile is

$$
R_{d, c}=\frac{R_{k, c}}{\gamma}
$$

where $R_{k, c}$ is the characteristic force and $\gamma$ is the partial coefficient of safety. Thus resulted $R_{d, c}=3,80 \mathrm{~N} / \mathrm{mm}^{2}$

The total number of piles $\left(n_{c}\right)$ needed from the condition of transmitting the forces from the structure to the soil will be:

$$
n_{c}=\beta \frac{V_{d, c}}{R_{d, c}}
$$

where $\beta$ is the coefficient depending on the size of the eccentricity.

Thus resulted $n_{c}=4200$ pieces.

Throughout the gravel piles technology, was achieved a compacting grade for the soil between the piles, capacity which wasn't taken into account in the design calculations. On site investigations revealed a capacity of $2,4 \times 10^{4} \mathrm{~N} / \mathrm{mm}^{2}$.

Following the costs analysis of the gravel piles soil improvement solution, resulted a value of $65 €$ for each square meter, thus meaning approximately $6,2 \%$ from the total investment price.

\section{Cement injection solution}

The solution consist in the injection of cement in bore holes with a rectangular layout. Site investigations have been made before and after soil imrpovement. 


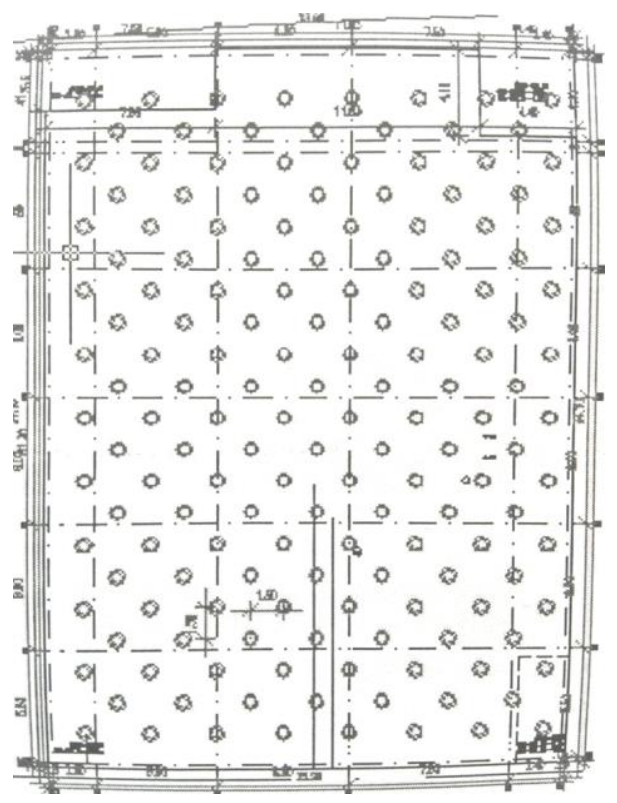

Figure 3. Cement injetion bore holes layout

The drilling for the holes were made at a distance of $1,5 \mathrm{~m}$ from each other axis, in depth until reaching the clay layer. The design calculations reveled a diameter of $30 \mathrm{~cm}$.

The cement quantity exceeded the total volume of the holes with approximately $60 \%$, meaning a discharge radius of $46 \mathrm{~cm}$.

Following the cement milk injection process, levelling and compacting of the excavation pit under the foundation slab, where done site investigations. The tests revealed the increase of the initial load capacity with approximately $40 \%$, reaching to $3,2 \times 10^{4}$ $\mathrm{N} / \mathrm{mm}^{2}$. The total cost of the soil improvement works was $35 €$ per square meter, which represent approximately $3,2 \%$ from the total investment costs.

\section{CONCLUSIONS}

Comparative analysis of the investigated soil improvement solutions led to the following conclusions:

- similar technological complexity of the processes/works

- reduced time in the process of cement injection solution

- ensuring soil load capacity in both solutions;

- load capacity ratio of 0,75 for the cement injection solution and with 0,15 ratio for the gravel pile solution

The cement injection solution proved to be the most economical and optimal solution. 
Contemporary achievements in civil engineering 22. April 2016. Subotica, SERBIA

\section{REFERENCES}

[1] Tuns, I. - Calculul și alcătuirea fundațiilor pe piloți, ed. Matrix Rom, București, 2007

[2] Indicativ C 29/IV-85 Îmbunătăţirea cu coloane din balast, nisip, piatră spartă şi alte materiale locale executate prin vibrare sau batere

[3] Indicativ NP 112-2014 - Normativul privind proiectarea fundaţiilor de suprafaţă.

[4] Standard roman Eurocod 7:Proiectarea geotehnica.Partea I:Reguli generale,SR EN 1997-1:2006

[5] Mantulescu M.,Tuns I.,A real estate foundation on improved ground in a residential area in Brasov,Proceedings of the International Conference DEDUCON-Sustainable Development in Civil Engineering ,Iasi 2011

[6] Note de Curs disciplina Reabilitarea şi consolidarea terenului de fundare - Prof. dr. ing. Tuns Ioan

[7] GP 114-2004- Ghid privind proiectarea si executia pilotilor forati 